\title{
IDENTIFIKASI SENYAWA AKTIF CRUDE EKSTRAK BUNGA LAWANG (Illicium verum) DAN UJI ANTIMIKROBIA PEMBUSUK DARI DAGING AYAM BROILER
}

Identification of Active Compounds in Crude Extracts Star Anise (Illicium verum) and Antimicrobial Activity for Microbe from The Broiler Chicken Meat

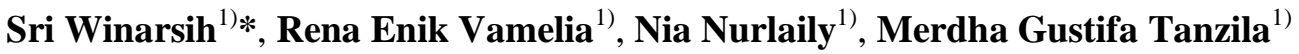 \\ ${ }^{1)}$ Prodi Ilmu dan Teknologi Pangan, Fakultas Pertanian Peternakan, \\ Universitas Muhammadiyah Malang \\ Jalan Raya TlogomasNo.246 Malang \\ *E-mail: sriwinarsih26@gmail.com
}

\begin{abstract}
Star anise is an important spicepart for human needs, commonly used as an enhancer of taste, color and aroma of the food.The purpose of this study were to identify the active compounds contained in crude extract star anise and its antimicrobial activity. In this study identified component of extract star anisewas extracted using maceration method for 24 hours. The result showed that the crude extract of star anise had 6 compounds as active compound by UPLC method i.e Orthidine E, Adriadysiolide, 8-Decene-4,6-diyne-1,2,10-triol, Chrysogedone A, Egomaketone, Lepalone. Crude extract of star anise also determined amount of total phenolic content and flavonoid content. Ethanolic extract contained 81.46 ppm of phenolic compound and 16.97 ppm of flavonoid. The crude extract of star anise about $6 \%$ concentration had highest antimicrobial activity with inhibition zone around $1.5 \mathrm{~cm}$ for the microbe isolated from the spoilage of broiler chicken meat.
\end{abstract}

Keywords: active component, antimicrobe activity, crude extract, Illium verum

\section{PENDAHULUAN}

Rempah-rempah di Indonesia berlimpah, berbagai jenis rempah dapat ditumbuhkan salah satunya adalah bunga lawang yang biasa dikenal sebagai pekak, bunga lawang memiliki bau yang khas dan kuat.Umumnya digunakan sebagai bahan perisa dalam minuman, juga penambah cita rasa masakan. Tanaman ini merupakan jenis pohon-pohonan atau perdu, dengan tinggi mencapai 4-6 m dan memiliki daun tunggal, berbintik dengan ujung runcing. Bunganya berwarna kuning kehijauhijauan. Buah terdiri atas 6-8 folikel, masing-masing folikel berisi 1 biji (Tjitrosoepomo, 2005). Buah berdiameter 2,5-4,5 cm. Buah ini tergolong rempahrempah dan terlihat seperti bintang berkepala empat simetris (Ong, 2008). Buah masak berwarna coklat dan akan pecah pada bagian tengahnya yang bentuknya menyerupai bintang. Pada setiap folikel buah yang pecah tadi terdapat biji berwarna coklat, mengkilap dan tidak berbulu (Ali et al., 2010).

Menurut Yazdani et al. (2009), bunga lawang berfungsi sebagai antifungal (anti jamur), antimikrobia (Borghin, et al. 2016), antioksidan (Yang et al., 2012), berpotensi sebagai anticancer (Bhadra et al., 2011) dan juga efektif mencegah dermatitis (Rudzki and Grzywa, 1976). Manfaat bunga lawang yang telah dibuktikan oleh para peneliti membuktikan bahwa dalam bunga lawang terkandung berbagai komponen bioaktif. Menurut Fardeau et al. (2013) bunga lawang mengandung poliphenols, flavonols (quercetin dan kaempferol), antosianin, tanins dan asam fenolik seperti shikimac dan asam galat.

Penggunaan bunga lawang yang masih terbatas pada perisa minuman dan penyedap makanan dirasa perlu 
dikembangkan lagi sesuai dengan komponen aktif yang terkandung didalamnya. Potensi yang bisa dikembangkan adalah sebagai pengawet alami untuk komoditi yang mudah mengalami kerusakan. Bahan pengawet alami dapat diperoleh dengan cukupmudah, untu memudahkan proses aplikasi sebagai pengawet, maka bunga lawang perlu diubah dalam bentuk ekstrak, yang perlu diuji aktivitasnya dalam produk yang ingin diawetkan.

Ayam boiler merupakan komoditi hasil peternakan yang mudah mengalami kerusakan. Kerusakan dapat disebabkan oleh benturan fisik, perubahan kimia dan aktivitas mikroba (Suparno, 2005). Oleh karena itu, perlu dilakukan cara untuk mengatasi kerusakan (pembusukan) yang disebabkan oleh aktivitas mikroba. Tujuan penelitian ini adalah untuk mengidentifikasi senyawa aktif yang terdapat dalam crude ekstrak bunga lawang dan menguji aktivitas antimikrobianya terhadap mikroba pembusuk dari daging ayam boiler.

\section{METODE PENELITIAN}

\section{Alat dan Bahan}

Alat yang digunakan untuk analisis para meter uji pada penelitian ini adalah mesin Ultra Perfomance Liquid Chromatography (UPLC) dengan detector Time of Flight-Mass Spectometry (TOFMS), Spektrofotomer UV-Vis, inkubator, dan lampu UV. Bahan utama yang digunakan untuk penelitian ini adalah daging ayam boiler yang disembelih langsung, bunga lawang kering dan etanol pro analisis, sedangkan bahan yang digunakan untuk analisis adalah reagen Folin-Ciocalteu, $\mathrm{Na}_{2} \mathrm{CO}_{3}$, asam galat, aquades, etanol 70\%, media nutrient agar (NA) sebagai media pertumbuhan mikroba.

\section{Tahapan Penelitian}

Penyiapan Crude Ekstrak

Bunga lawang dicuci dan dikeringanginkan selama 6 jam untuk hingga kering. Bunga lawang kemudian dihancurkan menggunakan blender dan diayak menggunakan ayakan berukuran 60 mesh. Serbuk bunga lawang yang telah dihasilkan ditambah pelarut etanol perbandingan 1:5. Proses ekstraksi dilakukan pada suhu ruang dan digojog menggunakan shaker dengan kecepatan 75 rpm selama 24 jam pada suhu ruang $\left(37^{\circ} \mathrm{C}\right)$. Ekstrak yang diperoleh akan di saring menggunakan kertas Saring Whatman No. 1, dan filtrat yang dihasilkan akan diperkatkan menggunakan evaporator wakum bersuhu $50^{\circ} \mathrm{C}$ hingga mencapai volume $1 / 4$ dari volume semula. Sisa etanol pada ekstrak pekat dihilangkan dengan cara dikeringkan menggunakan gas Nitrogen.

Analisis Total Fenol, Total Flavonoid (Khatiwora et al., 2010)

Ekstrak bunga lawang ditimbang sebanyak $100 \mathrm{mg}$ kemudian dilarutkan sampai $10 \mathrm{~mL}$ dengan aquades sehingga diperoleh konsentrasi $10 \mathrm{mg} / \mathrm{mL}$. Dari konsentrasi $10 \mathrm{mg} / \mathrm{mL}$ dipipet $1 \mathrm{~mL}$ dan diencerkan dengan aquades hingga $10 \mathrm{~mL}$ dan diperoleh konsentrasi ekstrak $1 \mathrm{mg} / \mathrm{mL}$. Larutan konsentrasi 1 $\mathrm{mg} / \mathrm{mL}$ dipipet sebanyak $0,2 \mathrm{~mL}$ ekstrak kemudian ditambahkan 15,8 mL aquades. Larutan ini $1 \mathrm{~mL}$ reagen FolinCiocalteu lalu dikocok. Didiamkan selama 8 menit kemudian ditambahkan $3 \mathrm{~mL}$ $\mathrm{Na}_{2} \mathrm{CO}_{3} 10 \%$ ke dalam campuran. Larutan didiamkan selama 2 jam pada suhu kamar, kemudian sampel diukur serapannya dengan spektrofotometer UV-Vis pada panjang gelombang serapan maksimum 765 nm. Dilakukan 3 (tiga) kali pengulangan sehingga kadar fenol yang diperoleh hasilnya didapat sebagai $\mathrm{mg}$ ekuivalen asam galat/g sampel segar. 
Analisis Senyawa Aktif Bunga Lawang menggunakan Ultra Perfomance Liquid Chromatography (UPLC) (Solikhah, 2016)

Pemisahan senyawa menggunakan UPLC bertujuan untuk identifikasi kualitatif senyawa dengan mendasarkan pada parameter waktu retensi. Pengujian ini dilakukan untuk mengetahui senyawa aktif yang terkandung dalam ekstrak bunga lawang yang diinjeksikan dalam mesin TOF-LCMS dan akan dideteksi dengan Flight-Mass Spectometry detector. Deteksi senyawa aktif pada bunga Lawang ekstrak Etanol menggunakan fasa diam berupa kolom Sunfire C18. Kolom C18 merupakan kolom dengan fasa terbalik dimana fasa diam C18 bersifat non polar dan fasa gerak bersifat polar. Kolom pengaman atau pra-kolom (guard column) yang digunakan berukuran 1,7 um dengan diameter $2,1 \times 50 \mathrm{~mm}$. Fase gerak yang digunakan dalam penelitian ini berupa 2 campuran yakni air $\left(\mathrm{H}_{2} \mathrm{O}\right)$ dengan $0,1 \%$ asam format $(\mathrm{HCOOH})$, asetonitril $\left(\mathrm{CH}_{3} \mathrm{CN}\right)$ dengan $0,1 \%$ asam format $(\mathrm{HCOOH})$.

\section{Aktifitas Antimikrobia (Metode Difusi Dengan Modifikasi (NCCLS, 1993)}

Aktivitas antimikrobia diuji menggunakan metode difusi cawan, yaitu dengan cara menuangkan $30 \mathrm{ml}$ media nutriet agar (NA) pada cawan petri, menunggu media agar mengeras. Setelah media agar mengeras, inokulum mikrobia yang diisolasi dari daging ayam broiler yang rusak ditebarkan di permukaan media nutrient agar (NA) dengan menggunakan mikropipet dan disebarkan merata dan diamkan selama 10 menit. Kemudian meletakkan kertas saring steril berdiameter $6 \mathrm{~mm}$ yang mengandung $50 \mu \mathrm{l}$ sampel diatas permukaan media agar. Kemudian media diinkubasi pada suhu $37^{\circ} \mathrm{C}$ selama 24 jam. Setiap sampel diulang sebanyak 3 kali.

\section{HASIL DAN PEMBAHASAN}

\section{Senyawa Aktif Bunga Lawang}

Identifikasi senyawa yang terdapat dalam crude ekstrak etanol bunga lawang diuji menggunakan UPLC with Ultra High Resolution Time of Flight-Mass Spectometry detector (TOF-MS) sebagaimana ditunjukkan pada Tabel 1. Sesuai dengan hasil uji ini, dapat diketahui bahwa ekstrak bunga lawang mengandung senyawa fenolik.

Senyawa fenolik adalah senyawa yang memiliki satu atau lebih gugus hidroksil yang menempel pada cincin aromatis. Senyawa fenolik yang teridentifikasi adalah orthidine E.Senyawa lain yang teridentifikasi adalah Adriadysiolide merupakan senyawa terpenoid,8-Decene-4,6-diyne-1,2,10triol,chrysogedone A, Egomaketone/perilla ketone dan Lepalone/5-(3-Furyl)-2methyl-1-penten-3-one.

\section{Total Fenol dan Flavonoid}

Dalam crude ekstrak bunga lawang terdapat senyawa fenolik sebesar 81,46 ppm. Penetapan kadar fenolik dalam ekstrak ditentukan dengan metode spektrofotometri dengan asam galat sebagai larutan standar.

Serapan maksimum asam galat diperoleh padapanjang gelombang 765 nmkonsentrasi ekstrak sebagai sampel uji ditetapkan sebesar $1 \mathrm{mg} / \mathrm{mm}$. Kandungan flavonoid pada crude ekstrak sebesar $16,97 \mathrm{ppm}$ sesuai dengan pernyataan Fardeau et al. (2013) bahwa bunga lawang juga mengandung flavonoid. Total fenol dan flavonoid ekstrak kasar bunga lawang ditunjukkan pada Tabel 2.

Tabel 2. Kadar fenol dan flavonoid ekstrak bunga lawang konsentrasi $1 \mathrm{mg} / \mathrm{ml}$

\begin{tabular}{lc}
\hline \multicolumn{1}{c}{ Komponen } & Jumlah (ppm) \\
\hline Fenolik & 81,46 \\
Flavonoid & 16,97 \\
\hline
\end{tabular}


Tabel 1. Senyawa aktif ekstrak kasar bunga lawang

\begin{tabular}{|c|c|c|c|}
\hline $\begin{array}{c}\text { Room } \\
\text { temperature } \\
\left({ }^{\circ} \mathrm{C}\right)\end{array}$ & Rumus molekul & $\begin{array}{l}\text { Prediksi nama } \\
\text { senyawa }\end{array}$ & Struktur molekul \\
\hline 5,37 & $\mathrm{C}_{18} \mathrm{H}_{22} \mathrm{~N}_{6} \mathrm{O}_{4}$ & Orthidine E & \\
\hline \multirow[t]{2}{*}{5,96} & $\mathrm{C}_{10} \mathrm{H}_{12} \mathrm{O}_{31}$ & Adriadysiolide & \\
\hline & $\mathrm{C}_{10} \mathrm{H}_{12} \mathrm{O}_{31}$ & $\begin{array}{l}\text { 8-Decene-4,6-diyne- } \\
\text { 1,2,10-triol }\end{array}$ & \\
\hline 6,49 & $\mathrm{C}_{10} \mathrm{H}_{15} \mathrm{NO}_{2}$ & Chrysogedone A & \\
\hline \multirow[t]{2}{*}{8,15} & $\mathrm{C}_{10} \mathrm{H}_{12} \mathrm{O}_{2}$ & $\begin{array}{l}\text { Egomaketone/ } \\
\text { Perilla ketone }\end{array}$ & \\
\hline & $\mathrm{C}_{10} \mathrm{H}_{12} \mathrm{O}_{2}$ & $\begin{array}{l}\text { Lepalone/5-(3-Furyl)- } \\
\text { 2-methyl-1-penten-3- } \\
\text { one }\end{array}$ & \\
\hline
\end{tabular}

Flavonoid termasuk ke dalam golongan senyawa fenolik. Flavonoid secara luas terdapat dalam tanaman, peranan senyawa ini beragam yaitu sebagai pemroduksi pigmen berwarna kuning, merah atau biru pada bunga, hingga sebagai penangkal terhadap mikroba dan insekta. Tabel 2 menunjukkan kandungan flavonoid dalam ekstrak kasar bunga lawang dengan konsentrasi $1 \mathrm{mg} / \mathrm{ml}$ sebesar 16,97 ppm, kandungan flavonoid dianalisis menggunakan spektrofotometri dengan standar kuersetin. Menurut Fardeau et al. (2013) jenis senyawa flavonoid yang terkandung dalam bunga lawang adalah 
golongan flavonol yaitu kuercetin dan kaempferol, sedangkan dari hasil identifikasi TOF-MS.

\section{Aktivitas Antimikrobia Bunga Lawang}

Aktivitas antimikrobia merupakan parameter untuk mengetahui kemampuan suatu zat atau senyawa dalam meminimalkan atau menghambat pertumbuhan mikrobia. Aktivitas antimikrobia ditetapkan menggunakan metode difusi cakram. Inokulum mikrobia pembusuk yang digunakan memiliki kepadatan sel $10^{9} \mathrm{cfu} / \mathrm{g}$.

Bhorgin et al. (2016) membuktikan bahwa ekstrak bunga lawang dalam methanol mampu menghambat pertumbuhan mikrobia patogen yaitu Escherichia coli, Staphylococcus aureus dan Candida albicans, secara berturutturut 7,45 $\pm 0,52 \mathrm{~mm}, 5,84 \pm 0,40 \mathrm{~mm}$, dan $5,62 \pm 0,39 \mathrm{~mm}$ pada konsentrasi ekstrak $1 \mathrm{mg} / \mathrm{ml}$. Pada daging ayam broiler yang sudah rusak (busuk) ditemukan beberapa mikroba coliform antara lain $B$. thermosphacta, Enterobacteriaceae dan Pseudomonas spp. yang menyebabkan rusaknya jaringan daging ayam dan bau busuk (Rouger et al., 2017).

Inokulum mikrobia yang dihambat dengan ekstrak kasar bunga lawang adalah mikrobia pembusuk yang diambil dari daging ayam broiler yang telah rusak (busuk). Diameter zona hambat mikrobia pembusuk daging ayam broiler terdapat pada Tabel 3.

Tabel 3. Diameter zona hambat ekstrak bunga lawang

\begin{tabular}{lc}
\hline Konsentrasi $(\%)$ & Diameter $(\mathrm{cm})$ \\
\hline 1 & 0,73 \\
2 & 1,1 \\
3 & 1,23 \\
4 & 1,33 \\
6 & 1,5
\end{tabular}

Tabel 3 menunjukkan bahwa ekstrak kasar bunga lawang yang diencerkan menggunakan aquades dengan konsentrasi $1-6 \%$ b/v mampu menghambat mikroba pembusuk pada daging ayam broiler. Aktivitas antimikroba tertinggi terdapat pada konsentrasi 6\% ekstrak kasar ditandai dengan $1,5 \mathrm{~cm}$ zona hambat. Diduga mikroba pembusuk yang dihambat pertumbuhannya adalah $B$. thermosphacta, Enterobacteriaceae dan Pseudomonas spp. sesuai dengan bakteri yang ada pada daging ayam broiler yang sudah rusak (Rouger et al., 2017).

Aktivitas antimikrobia dari ekstrak dipengaruhi oleh adanya senyawa fenolik dan berbagai senyawa metabolit sekunder yang belum teridentifikasi dari UPLC with Ultra High Resolution Time of FlightMass Spectometry detector (TOF-MS) dalam ekstrak. Menurut Bhorgin et al. (2016) aktivitas anti-mikrobia juga dipengaruhi oleh gugus hydroksil dalam gugus aktif dalam metabolit sekunder, karena kemampuan komponen ini untuk berikatan dengan bakteri dan akhirnya menganggu kinerja reseptor pada permukaan bakteri. Menurut Bluma et al. (2008) komponen fenolik dalam bunga lawang berperan dalam pembentukan dinding penghalang (building block) dalam struktur dinding sel yang akan berperan sebagai penghalang terhadap terinfeksinya mikrobia pathogen.

Penggunaan inokulum mikrobia dari daging ayam bertujuan untuk mengetahui secara langsung berapa besar kemampuan ekstrak kasar bunga lawang dalam menghambat pertumbuhan mikrobia pembusuk dari daging ayam broiler. Data tersebut selanjutnya digunakan sebagai dasar penggunaan ekstrak bunga lawang sebagai pengawet alami daging ayam broiler.

\section{KESIMPULAN}

Ekstrak kasar bunga lawang mengandung senyawa Orthidine E, Adriadysiolide, 8-Decene-4,6-diyne- 
1,2,10-triol, Chrysogedone A, Egomaketone, dan Lepalone. Ekstrak kasar (crude) bunga lawang dapat menghambat mikrobia yang teridentifikasi sebagai coliform yang diisolasi dari daging ayam broiler yang rusak. Konsentrasi ekstrak bunga lawang $6 \% \mathrm{~b} / \mathrm{v}$ menghasilkan antimikrobia tertinggi terhadap mikroba pembusuk daging ayam broiler yang dibuktikan dengan adanya zona hambat sebesar $1,5 \mathrm{~cm}$.

\section{UCAPAN TERIMA KASIH}

Ucapan terima kasih kepada Kemenristekdikti yang telah mendanai penelitian ini melalui Program Kreatifitas Mahasiswa tahun 2017 dan pendanaan Block Grant Fakultas Pertanian Peternakan Universitas Muhammadiyah Malang tahun 2017.

\section{DAFTAR PUSTAKA}

Ali, K., Sutaryo, Purwanto, I., Mulatsih, Supriyadi, E., 2010. Yogyakarta pediatric cancer registry: An International collaborative project of University Gadjah Mada, University of Saskatchewan, and the Saskatchewan Cancer Agency.Asian Pasific Journal of Cancer Prevention, 11: 131-136.

Awoyinka, O., Balogun, I. O., Ogunnowo, A. A., 2007. Phytochemical screening and in-vitro bioactivity of Cnidoscolus aconitifolius (Euphorbiaceae). J. Med. Plant Res., 1(3): 63-65.

Bhadra, S., Mukherjee, P.K., Kumar, N.S., and Bandyopadhyay, A. (2011) Anticholinesterase activity of standardized extract of Illicium verum Hook.f. fruits. Fitoterapia,82(3): 342346.

Bluma, R. V., and Etcheverry, M. V.2008. Application of essential oils in maize grain: impact on Aspergillus section Flavi growth parameters and aflatoxin accumulation. Food Microbiol., 25 (2): 324-334.
Bhorgin Lourdu Mary A. J., and Perumal, U.M. 2016. Characterization and anti microbial effect of methanolic extract of Illucium verum on pathogenic bacteria. World Journal of Pharmacy and Pharmaceutical Science., 5 (9): 2040-2054.

Fardeau, M. L., Benmalek, Y., Yahia, O. A., and Belkebir, A. 2013. Anti-microbial and anti-oxidant activities of Illicium verum, Crataegus oxyacantha ssp Monogyna and Allium cepa red and white varieties. Bioengineered Journal, 4 (4): 244-248.

NCCLS. 1993. National Committee for Clinical Laboratory Standards. Performance standards for antimicrobial disc susceptibility tests. PA: NCCLS Publications, 2-5.

Nazrul, M., Daud, H., AbdullahN., and Ahmad, R. 2018. Bioassay-guided Fractionation of Artocarpus heterophyllus L. J33 variety fruit waste extract and identification of its antioxidant constituents by TOF-LCMS. J. Food Chemistry, 266: 200-214.

Rouger, A., O. Tresse, M. Zagorec. 2017. Bacterial contaminants of poultry meat: Sources, species, and dynamics Microorganisms Journal, 5 (50): 216.

Rudzki, E., and Grzywa. Z. 1976. Sensitizing and irritating properties of star anise oil. Contact Dermatitis, 2 (6): 305-8.

Suparno. 2005. Ilmu dan Teknologi Daging. Edisi Keempat. Gadjah Mada University Press, Yogyakarta.

Sholikhah, R.M. 2016. "Identifikasi Senyawa Triterpenoid dari Fraksin-Heksana Ekstrak Rumput Bambu (Lophatherum gracile Brongn) dengan Metode UPLCMS". Skripsi. Univ. Maulana Malik Ibrahim, Malang.

Tjitrosoepomo, G. 2005. Taksonomi Tumbuhan (Spermatophyta). UGMPress, Yogyakarta. 
Ong, H.C., Bunga Lawang. In H.C., Ong (Ed.). 2008. Rempah-Ratus: Khasiat Makanan \& Ubatan. Utusan Publication \& Distributors Sdn. Bhd 94., Malaysia.

Yang, J.F., Yang, C.H., Chang, H.W., Yang, C.S., Wang, S.M., Hsieh, M.C., and Chuang, L.Y. 2010. Chemical composition and antibacterial activities of Illicium verum against antibiotic-resistant pathogens. J. Med. Food, 13: 1-9.

Yazdani, D., Rezazadeh, S., Amin, G., Zainal, A., Shahnazi S., and Jamalifar H. 2009. Antifungal activity of dried extracts of anise (Pimpinella anisum L.) and star anise (Illicium verum Hook. f.) against dermatophyte and saprophyte fungi. Journal of Medicinal Plants, 8 (5): 24-29. 